\title{
The Effectiveness of Using the Lecture Method at SMK Negeri 1 Parepare
}

\author{
Muhammad Iqram Ikhsan, Risma Niswaty, Sirajudddin Saleh, Sitti Hardiyanti \\ Arhas \\ Pendidikan Administrasi Perkantoran, Universitas Negeri Makassar \\ E-mail: risma.niswaty@unm.ac.id
}

(Received: January-2019; Reviewed: February-2019; Accepted: March-2019;

Avalaibel Online: March 2019; Published: March-2019)

This is an open access article distributed under the Creative Commons Attribution License

CC-BY-NC-4.0 @2019 by author (https://creativecommons.org/licenses/by-nc/4.0/)

\begin{abstract}
This study aims to determine the effectiveness of the use of lecture methods in class X introductory subjects administrative office administration department SMK Negeri 1 Parepare. This research uses a type with qualitative descriptive approach. Informants in this study as many as five people. Data collection is done through interview technique, observation, and documentation. The results showed that. Teachers have applied the learning process such as, doing the preparation stage of learning well, performing the implementation phase starting from the opening step until the presentation step has been done optimally, and the last to do the ending stage by giving opportunity to the students to conclude the material taught and doing evaluation to students has been done quite effectively. So the use of lecture methods in class $\mathrm{X}$ introductory subjects administrative office administration department of SMK Negeri 1 Parepare run effectively.
\end{abstract}

Keywords: Effectiveness; Lecture Method; Education

\section{INTRODUCTION}

Education is a conscious effort to educate a nation that is in line with the opening of the 1945 Constitution of the 4th century and wants to achieve the goal of national education. Today's development requires quality human resources so that they are able to compete with other developed countries today. Education has a very important role in creating quality human resources (Mazlan, Redzuan, \& Bakar, 2014; Morin, Robert, \& Gabora, 2018; Morineau, Meineri, \& Chapelain, 2017; Thorburn, 2018; Tirthali, 2012). Quality education will affect progress in various fields. In addition to pursuing quality education, the government needs to equalize basic education for every Indonesian citizen, in order to be able to participate in advancing the life of the nation (Rengifurwarin, Akib, \& Salam, 2018; Saggaf, Salam, Darwis, \& Jamaluddin, 2017; Saggaf, Salam, \& Rifka, 2017). 
Based on RI Law No. 20 of 2013 Chapter 1 Article 1 paragraph 1 cited in Sanjaya on defining national education. Education is a conscious and planned effort to create an atmosphere of learning and learning process so that students effectively develop their potential to have spiritual spiritual strength, self-control, personality, intelligence, noble character and the skills needed by themselves, society, nation and state.

According to Hidayat The main task of an educator according to the teacher and lecturer law article 1 paragraph 1 is "educating, teaching, guiding, directing, training, evaluating and evaluating students". To be able to carry out these tasks properly, educators must be able to master a variety of abilities. One of the skills that must be mastered is to develop themselves professionally (Elvasusanti, Syamsudduha, \& Rahman, 2019; Johari et al., 2009; Krishna, Rofaida, \& Sari, 2010; Niswaty, Rusbiati, Jamaluddin, \& Salam, 2017; Nur, Rahman, \& Musdalifa, 2019; Saggaf, Nasriyah, Salam, \& Wirawan, 2018; Sukmawati, Jamaluddin, Niswaty, \& Asmanurhidayani, 2019). This means, educators are not only required to master teaching material or be able to present it appropriately, but are also required to be able to assess their own performance. This ability is related to research which is mainly focused on the circumstances surrounding the classroom, namely research in the classroom itself.

An educator must have the ability to manage the teaching and learning process well, through various techniques or methods of delivering appropriate material in accordance with the material being taught and the ability of students (Goulet, 1994; Gruber, 1995; Mayo, 1995). As we know, teaching methods are the target of interaction between teachers and students. Thus, what must be considered in teaching is the accuracy between the learning objectives and the methods used (Rengifurwarin et al., 2018; Saggaf, Salam, Darwis, et al., 2017; Saggaf, Salam, \& Rifka, 2017). According to Sanjaya the method is "the method used to implement plans that have been prepared in real activities so that the objectives that have been prepared are optimally achieved. This means, the method is used to realize the strategy set".

One of the most commonly used learning methods is the lecture learning method. It is different from other learning methods, for example the question and answer method, the discussion method, the recitation / task method, the demonstration method, and others. Lecture learning method, is a traditional or classical method that has long been used in education. In this method teachers are required to be active in teaching activities.

\section{METHOD}

This research uses a qualitative approach. The researcher works by considering the observed symptoms and utilizing field notes regarding the effectiveness of using the lecture method in class $\mathrm{X}$ introductory subjects of office administration majoring in office administration at SMK Negeri 1 Parepare. This research is a qualitative descriptive study, a research that illustrates narratively based on research data that has been objectively based on interviews, observations, and documentation. Results data obtained from various data sources to answer various kinds of research problems, namely: Primary Data is data obtained from interviews that contain questions relating to the effectiveness of using the lecture method, obtained from research informants, namely: a) Chair Department of Office Administration 1 Parepare Vocational School 1 person, b) Guardian of Class X majoring in office administration 1 person, c) Filing teacher for 1 person, d) Class X students are 2 people. 


\section{RESULT AND DISCUSSION}

Based on the results of research conducted by researchers on the Effectiveness of the use of lecture methods in class $\mathrm{X}$ subjects introductory office administration majoring in office administration SMK 1 Parepare in general can be said to have been running effectively. This can be seen from several informants' explanations based on the process carried out by the introductory subject teacher in office administration starting from the preparation, implementation and ending stages that have been carried out by the teacher.

\section{Stages of Preparation}

The preparation phase is a short-term planning for estimating and making a picture of what will be done or the actions we will take in the classroom during the learning process. In general, introductory subject teachers have made effective learning preparation. The preparation phase carried out by the teacher is based on the syllabus and lesson plans that have been made previously. On this basis the teacher can prepare learning tools that will be used when the learning process is taking place. This learning is based on syllabus and lesson plans that have been made by the teacher before. The teacher determines the objectives to be achieved in order to determine what actions must be taken by the teacher during the learning process goes on.

\section{Implementation Stage}

The implementation phase is the stage where the operational learning activities themselves. In this stage the teacher interacts with students in the form of teaching and learning through the lecture method. At the implementation stage for the lecture method delivered by the introductory subject teacher office administration in the learning process there are two implementation steps, namely the opening step and the presentation step.

The opening step is the step that determines the success of the lecture method. In this step the teacher must be sure that the objectives taught can be understood by students. The teacher first explains to students the learning objectives to be achieved, so that students can know what they will receive from the material taught by the introductory office administration subject teacher. Meanwhile the presentation step is a step of delivering the material by the teacher. So that students can receive the subject matter well, the teacher is expected to maintain eye contact to students from the beginning of the lesson until the end of class time. By paying attention to the students' eyes, the teacher can know the direction of the student's concentration. Maintaining eye contact can also make students pay attention to the material presented by the teacher in front of the class. In addition to maintaining eye contact with students, there is another thing that mediates the focus of students on the subject matter, which is the language used by the teacher in presenting the material.

\section{Steps to End or Close the Lecture}

A teacher who uses the lecture method must be closed so that lessons that are understood and mastered by students do not fly back. The teacher can create activity that can enable students to keep remembering the learning material.

\section{CONCLUSION}


The use of lecture method in class $\mathrm{X}$ introductory office administration majors majoring in office administration at SMK Negeri 1 Parepare has been running effectively. This can be seen in the preparation stage, the implementation stage and the ending or closing the lecture that has been running according to the established standards. That the teacher has implemented a learning process such as, carrying out the preparatory stages of learning well, carrying out the implementation phase starting from the opening step until the presentation step has been carried out optimally, and finally completing the stage by giving the opportunity to students to conclude the material being taught and evaluating students has been done quite effectively.

\section{REFERENCES}

Elvasusanti, E., Syamsudduha, S., \& Rahman, U. (2019). The Effect of Madrasah Head Leadership Style and Work Motivation on Work Discipline of Madrasah Aliyah Teachers. Jurnal Ilmiah Ilmu Administrasi Publik, 9(1), 1-8.

Goulet, D. (1994). Participatory technology assessment: Institution and methods. Technological Forecasting and Social Change, 45(1), 47-61. https://doi.org/https://doi.org/10.1016/0040-1625(94)90062-0

Gruber, S. (1995). Re: Ways we contribute: Students, instructors, and pedagogies in the computer-mediated writing classroom. Computers and Composition, 12(1), 61-78. https://doi.org/https://doi.org/10.1016/8755-4615(95)90023-3

Johari, K., Ismail, Z., Osman, S., Othman, A. T., Khalid, J., Zurida, I., ... ahmad tajuddin, O. (2009). Pengaruh Kelayakan Guru ke atas Efikasi Guru-guru Sekolah Menengah. Jurnal Pendidikan Malaysia.

Krishna, A., Rofaida, R., \& Sari, M. (2010). Analisis Tingkat Literasi Keuangan(Survey pada Mahasiswa Universitas Pendidikan Indonesia). Proceedings of The 4th International Conference on Teacher Education; Join Conference UPI \& UPSI Bandung, Indonesia.

Mayo, P. (1995). Critical literacy and emancipatory politics: The work of Paulo Freire. International Journal of Educational Development, 15(4), 363-379. https://doi.org/https://doi.org/10.1016/0738-0593(95)00021-T

Mazlan, D., Redzuan, A. M., \& Bakar, D. A. (2014). Consumer Education in Creating a Consumer Conscious Nation. Procedia - Social and Behavioral Sciences, 155, 448-453. https://doi.org/https://doi.org/10.1016/j.sbspro.2014.10.320

Morin, S., Robert, J.-M., \& Gabora, L. (2018). How to train future engineers to be more creative? An educative experience. Thinking Skills and Creativity, 28, 150-166. https://doi.org/https://doi.org/10.1016/j.tsc.2018.05.003

Morineau, T., Meineri, S., \& Chapelain, P. (2017). Cognitive control level of action for analyzing verbal reports in educative clinical simulation situations. Nurse Education Today, 50, 104-108. https://doi.org/https://doi.org/10.1016/j.nedt.2016.12.016

Niswaty, R., Rusbiati, S., Jamaluddin, J., \& Salam, R. (2017). The Influence of Teacher's 
Reinforcement for Students Motivation. International Conference on Education, Science, Art and Technology, 148-152.

Nur, F., Rahman, U., \& Musdalifa, M. (2019). Effect of Motivation and Job Satisfaction on Teacher Performance in Private Madrasah Aliyah in Maros Regency. Jurnal Ilmiah Ilmu Administrasi Publik, 9(1), 9-18.

Rengifurwarin, Z. A., Akib, H., \& Salam, R. (2018). Snapshot of public service quality in the center for integrated business service (CIBS), cooperative micro small and medium enterprises (CMSME), Maluku Province, Indonesia. Journal of Entrepreneurship Education.

Saggaf, M. S., Nasriyah, N., Salam, R., \& Wirawan, H. (2018). The Influence of Teacher's Pedagogic Competence on Learning Motivation of Student of Office Administration Expertise Package.

Saggaf, M. S., Salam, R., Darwis, M., \& Jamaluddin, M. (2017). Examining Academic Service using Importance Performance Analysis (IPA). 2nd International Conference on Education, Science, and Technology (ICEST 2017). Atlantis Press.

Saggaf, M. S., Salam, R., \& Rifka, R. (2017). The Effect of Classroom Management on Student Learning Outcomes. International Conference on Education, Science, Art and Technology, 98-102.

Sukmawati, S., Jamaluddin, J., Niswaty, R., \& Asmanurhidayani, A. (2019). The Influence of Headmaster Leadership Style on Teacher Performance. Jurnal Office, 4(2), 91-102.

Thorburn, M. (2018). John Dewey, subject purposes and schools of tomorrow: A centennial reappraisal of the educational contribution of physical education. Learning, Culture and Social Interaction, 19, 22-28. https://doi.org/https://doi.org/10.1016/j.lcsi.2018.04.001

Tirthali, D. (2012). Educating About Diabetes: Conversations on a Social Network Site. Procedia - Social and Behavioral Sciences, 46, 3732-3737. https://doi.org/https://doi.org/10.1016/j.sbspro.2012.06.137 
156 Pinisi Discretion Review

Volume 2, Issue 2, March, 2019 Page. 151-156 